\title{
Powikłania płucne u chorych na drobnokomórkowego raka płuca w ograniczonej postaci z całkowitą remisją po radiochemioterapii
}

\author{
Beata Sas-Korczyńska ${ }^{1}$, Andrzej Sokołowski², \\ Elżbieta Włodarczyk ${ }^{1}$, Elżbieta Łuczyńska ${ }^{3}$
}

Cel. Celem pracy jest przedstawienie wyników analizy wpływu wybranych czynników na częstość rozwoju powikłań płucnych u chorych z całkowitą remisją (CR) po radiochemioterapii (RT-ChT) stosowanej z powodu drobnokomórkowego raka płuca w ograniczonej postaci (DKRP OP).

Materiał i metody. W latach 2000-2010 u 286 chorych na DKRP OP zastosowano leczenie skojarzone RT-ChT jako leczenie równoczesne (157 chorych - 54,9\%) lub w układzie sekwencyjnym (129 chorych — 45,1\%). Uwzględniając czas rozpoczęcia radioterapii obszaru klatki piersiowej w stosunku do prowadzenia chemioterapii, wyróżniono: RT rozpoczynaną po 1-2 cyklu chemioterapii (zastosowana u 104 chorych - 36,4\%) oraz RT rozpoczynaną po 3. cyklu lub później (przeprowadzona u pozostałych 182 chorych - 63,4\%). Powikłania w płucach oceniono u chorych, u których po RT-ChT uzyskano CR, a minimalny okres obserwacji po leczeniu wynosił 6 miesięcy. Radiologiczne badania obrazowe klatki piersiowej były podstawą do stwierdzenia obecności rozwoju powikłań w płucach, do których wykorzystano klasyfikację proponowaną przez Fleischner Society. Stopień nasilenia powikłań oceniony został według Common Terminology Criteria for Adverse Events (CTCAE). Przeprowadzono analizę wpływu terapeutycznych i klinicznych czynników na częstość rozwoju powikłań. Ponadto oszacowano odsetek przeżycia bez objawów nowotworu w odniesieniu do tych czynników, które okazały się istotnymi dla rozwoju powikłań.

Wyniki. Spośród wszystkich chorych u 187 (65,4\%) po RT-ChT uzyskano CR. Okres obserwacji wynoszący przynajmniej 6 miesięcy dotyczył 152 chorych (81,3\%). Spośród tych chorych u 132 (86,8\%) stwierdzono rozwój powikłań w płucach. Stanowili oni 70,6\% chorych z CR. Zwłóknienie płuc stwierdzono u 91 chorych (48,7\% ogólnej liczby i 48,7\% chorych z CR). Innymi objawami radiologicznymi stwierdzanymi w płucach były:zagęszczenie pęcherzykowo-zrębowe $(74$ chorych — 56,1\%) i pogrubienie rysunku zrębu ( 24 chorych - 18,2\%), które współistniały ze zwłóknieniem (54 chorych) lub występowały samodzielnie (41 chorych). Wykazano, że rozwój powikłań w płucach istotnie zależał od sposobu zastosowania RT-ChT (93,3\% vs 80,5\% odpowiednio dla równoczesnej i sekwencyjnej) oraz od czasu rozpoczynania RT obszaru klatki piersiowej (95,6\% vs 79,8\% odpowiednio dla RT po 1-2 cyklu i RT po 3 cyklu lub później). Po uwzględnieniu powyższych czynników wykazano istotny wpływ maksymalnej dawki w płucach, średniej dawki w płucach oraz wartości V20 na rozwój powikłań w płucach.

Wnioski. Schemat Rt-ChT oraz czas rozpoczynania radioterapii względem chemioterapii są istotnymi czynnikami wpływającymi nie tylko na wyniki leczenia (przeżycia bez objawów nowotworu), ale również na rozwój powikłań w płucach.

\section{Pulmonary complications in patients with complete remission after radio-chemotherapy} for localized stage small-cell lung cancer

Aim. The study aimed to analyse the effects of selected factors on the frequency of pulmonary complications in patients with localized stage small-cell lung cancer (LSSCLC) in complete remission (CR) following radio-chemotherapy (RT-ChT).

\footnotetext{
${ }^{1}$ Klinika Onkologii, Oddział Nowotworów Piersi i Klatki Piersiowej

Centrum Onkologii — Instytut im. Marii Skłodowskiej-Curie, Oddział w Krakowie

${ }^{2}$ Katedra Statystyki

Uniwersytet Ekonomiczny w Krakowie

${ }^{3}$ Zakład Diagnostyki Obrazowej
}

Centrum Onkologii — Instytut im. Marii Skłodowskiej-Curie, Oddział w Krakowie 
Material and methods. Between 2000 and 2010, 286 patients with LS SCLC received RT-ChT. Treatment was given sequentially (157 patients - 54.9\%) or concurrently (129 patients - 45.1\%). According to the start of thoracic radiotherapy (RT) in relation to chemotherapy, the two groups were selected: RT started immediately after 1-2 cycles of chemotherapy (it was applied in 104 patients - 36.4\%). The other 182 patients (63.4\%) received RT after 3 or cycles of chemotherapy or later. Pulmonary complications were evaluated in patients with complete remission (CR) with a minimum follow-up period of 6 months. These complications found on radiological chest examinations were assessed according to classification proposed by the Fleischner Society. The severity of these pulmonary changes was assessed according to Common Terminology Criteria for Adverse Events (CTCAE). The frequency of lung complications and the influence of some therapeutic and clinical parameters to the development of pulmonary complications were evaluated. In addition the disease-free survival (DFS) rate was estimated in relation to factors that significantly influenced the frequency of pulmonary complications.

Results. A total of 187 patients (65.4\%) achieved CR following RT-ChT. For 152 patients (81.3\%) the duration of follow-up was at least 6 months. Pulmonary complications were observed in 132/152 patients (86.8\%). These patients accounted for $70.6 \%$ of those with CR. Pulmonary fibrosis was observed in 91 patients (48.7\%) and these patients accounted for $48.7 \%$ of those with CR. Other signs of lung complications were ground-glass opacities (74 patients $-56.1 \%)$ and interlobular septal thickening (24 patients - 18.2\%). These changes were either accompanied by fibrosis (54 patients) or appeared independently (41 pts.).

The incidence of pulmonary complications significantly correlated with the schedule of RT-ChT (93.3\% vs $80.5 \%$ for concurrent vs sequential) and the beginning of thoracic RT ( $95.6 \%$ vs $79.8 \%$ for RT after $1-2$ cycles ChT vs RT after 3 or later). The significant differences related to maximum lung dose, mean lung dose and V20 were demonstrated after taking into account the schedule of RT-ChT and the start of thoracic RT.

Conclusions. In patients with LS SCLC the schedule of radio-chemotherapy and timing of thoracic radiotherapy have a significant impact not only on the results of treatment (disease-free survival rate) but also on the incidence of pulmonary complications in patients with LS SCLC.

NOWOTWORY Journal of Oncology 2014; 64, 5: 383-390

Słowa kluczowe: drobnokomórkowy rak płuca, radiochemioterapia, powikłania w płucach, zwłóknienie płuc, średnia dawka w płucach

Key words: small-cell lung cancer, radio-chemotherapy, lung complications, pulmonary fibrosis, mean lung dose

\section{Wstęp}

Drobnokomórkowy rak płuca (DKRP) stanowi 10-15\% wszystkich pierwotnych nowotworów złośliwych płuc [1]. Charakteryzuje go szybkie tempo proliferacji komórek, czego skutkiem jest wysoka wrażliwość na chemioterapię i radioterapię. Równocześnie nowotwór ten cechuje się agresywnym przebiegiem klinicznym, co przejawia się wczesnym i częstym rozwojem przerzutów odległych.

Standardowym postępowaniem terapeutycznym u chorych na DKRP w ograniczonej postaci (OP) jest leczenie skojarzone: radiochemioterapia (RT-ChT), po której w przypadku uzyskania remisji przeprowadzane jest profilaktyczne napromienianie mózgu [2-12].

Wyniki przeprowadzonych metaanaliz wykazały, że stosowanie równoczesnej RT-ChT istotnie wpływa na poprawę wyników leczenia, co przejawia się poprzez zwiększenie o 5,4\% odsetek 2-letnich przeżyć. Szczególnie pozytywny wpływ na wyniki leczenia widoczny jest w przypadku wczesnego rozpoczynania radioterapii (RT) na obszar nowotworu w klatce piersiowej (tj. podczas pierwszych cykli chemio- terapii). Zysk ten, w porównaniu z leczeniem stosowanym sekwencyjnie, wynosi wówczas 5,2\% [13-17].

Stosowanie leczenia skojarzonego, szczególnie równoczesnej RT-ChT, jest czynnikiem wpływającym na pogorszenie tolerancji leczenia, co przejawia się zwiększeniem częstości nasilenia objawów niepożądanych, zarówno wczesnych (wszystkim powikłań hematologicznych i zapalenia przełyku), jak i późnych (powikłania płucne) [18-23].

Skuteczne sposoby leczenia z jednej strony umożliwiają uzyskanie całkowitej remisji (CR) oraz wpływają na wydłużenie czasu przeżycia, a z drugiej strony obciążone są ryzykiem wystąpienia powikłań, wpływających na pogorszenie jakości życia chorych. Jest to szczególnie istotne w przypadku tych chorych, u których uzyskano całkowitą remisję nowotworu, skutkiem czego jest uzyskanie przeżycia bez objawów nowotworu.

Celem pracy jest przedstawienie wyników analizy wpływu wybranych czynników klinicznych i czynników związanych z leczeniem na częstość rozwoju powikłań płucnych u chorych z całkowitą remisją po radiochemioterapii (RT-ChT) 
Tabela I. Charakterystyka kliniczna i parametry terapeutyczne w całej grupie 286 chorych na DKRP OP oraz w podgrupie 152 chorych z całkowitą remisją po radiochemioterapii i okresem obserwacji po leczeniu wynoszącym przynajmniej 6 miesięcy

\begin{tabular}{|c|c|c|c|c|}
\hline \multirow[t]{2}{*}{ Czynniki } & \multicolumn{2}{|c|}{$\begin{array}{l}\text { Cała grupa DKRP OP } \\
\text { (286 chorych) }\end{array}$} & \multicolumn{2}{|c|}{$\begin{array}{c}\text { Pacjenci z CR i obserwacją } \geq 6 \text { mies. } \\
\text { (152 chorych) }\end{array}$} \\
\hline & Liczba & $\%$ & Liczba & $\%$ \\
\hline \multicolumn{5}{|l|}{ Płeć: } \\
\hline kobiety & 93 & 32,5 & 63 & 41,4 \\
\hline mężczyźni & 193 & 67,5 & 89 & 58,6 \\
\hline \multicolumn{5}{|l|}{ RT-ChT: } \\
\hline równoczesna & 129 & 45,1 & 75 & 49,3 \\
\hline sekwencyjna & 127 & 54,9 & 77 & 50,7 \\
\hline \multicolumn{5}{|l|}{ Liczba cykli PE (3-6): } \\
\hline$<4$ & 26 & 9,1 & 9 & 5,9 \\
\hline$\geq 4$ & 260 & 90,9 & 143 & 94,1 \\
\hline \multicolumn{5}{|c|}{ Rozpoczynanie RT obszaru klatki piersiowej — po: } \\
\hline $1-2$ cyklu PE & 104 & 36,4 & 68 & 44,7 \\
\hline$\geq 3$ cyklu & 182 & 63,4 & 84 & 55,3 \\
\hline \multicolumn{5}{|c|}{ Dawka całkowita (PTV): } \\
\hline$<50 \mathrm{~Gy}$ & 20 & 7,0 & 11 & 7,2 \\
\hline$\geq 50 \mathrm{~Gy}-<54 \mathrm{~Gy}$ & 44 & 15,4 & 18 & 11,8 \\
\hline$\geq 54 \mathrm{~Gy}-\leq 56 \mathrm{~Gy}$ & 193 & 67,5 & 111 & 73,0 \\
\hline$>56 \mathrm{~Gy}$ & 29 & 10,1 & 12 & 7,9 \\
\hline
\end{tabular}

DKRP OP — drobnokomórkowy rak płuca w ograniczonej postaci, CR — całkowita remisja, RT-ChT — radiochemioterapia, PE — schemat chemioterapii: cisplatyna i etopozyd, RT — radioterapia, PTV (planning target volume) — planowana objętość w radioterapii

stosowanej z powodu drobnokomórkowego raka płuca w ograniczonej postaci (DKRP OP).

\section{Materiał i metody}

W okresie 2000-2010 w Centrum Onkologii — Instytucie im. Marii Skłodowskiej-Curie, Oddziale w Krakowie, u 286 chorych na DKRP OP zastosowano leczenie skojarzone RT-ChT.

U wszystkich chorych ograniczona postać DKRP została potwierdzona w badaniach obrazowych (radiologiczne zdjęcie klatki piersiowej, komputerowa tomografia klatki piersiowej i jamy brzusznej, ultrasonografia jamy brzusznej, magnetyczny rezonans jądrowy albo komputerowa tomografia mózgu) oraz scyntygrafii kośćca.

Wiek omawianych chorych wahał się od 32 do 79 lat (średnia 59,9 roku, mediana: 59 lat). Charakterystyka kliniczna i dane dotyczące leczenia omawianej grupy chorych przedstawione zostały w tabeli l.

Wszyscy chorzy otrzymali chemioterapię (ChT) według schematu EP (etopozyd, cisplatyna), z czego 260 chorych (90,9\%) otrzymało 4-6 cykli. Radioterapia na obszar nowotworu w klatce piersiowej u 157 chorych $(54,9 \%)$ stosowana była w układzie sekwencyjnym (tj. po zakończeniu ChT). U pozostałych 129 chorych $(45,1 \%)$ zastosowano równoczesną RT-ChT, gdzie RT na obszar klatki piersiowej rozpoczynana była po 1-3. cyklu ChT.

Uwzględniając czas rozpoczynania RT względem ChT, u 104 chorych $(36,4 \%)$ rozpoczynana ona była po 1-2. cyklu ChT, a u pozostałych 182 chorych $(63,4 \%)$ - po 3 . lub po kolejnych cyklach ChT.
Radioterapia na obszar nowotworu w klatce piersiowej stosowana była w warunkach terapii megawoltowej z zastosowaniem wiązki fotonowej, w której stosowane były konformalne techniki radioterapii, z wykorzystaniem trójwymiarowego systemu planowania leczenia. Definicja GTV (gross tumour volume - objętości wzrostu nowotworu) określana była na podstawie skanów tomografii komputerowej i zaliczano do niej obszar pierwotnego nowotworu i zajętych węzłów chłonnych. W pierwszym etapie radioterapii CTV (clinical target volume - kliniczna objętość) obejmowała GTV i węzły śródpiersia z odpowiednimi marginesami, natomiast w drugim etapie radioterapii CTV powstawała poprzez dodanie marginesu $8 \mathrm{~mm}$ wokół GTV. W obu etapach leczenia PTV (planning target voulme - objętość planowana w radioterapii) tworzono poprzez dodanie marginesów $7 \mathrm{~mm}$ w wymiarze poprzecznym i 12 mm w wymiarze podłużnym. Dawka całkowita wahała się od 40 do 66 Gy i wynosiła średnio 53,2 Gy (mediana: $54 \mathrm{~Gy}$ ). Dawka frakcyjna wynosiła 1,8-2,0 Gy. Większość chorych (222 spośród 286 - 77,6\%) otrzymała dawkę równą lub większą od $54 \mathrm{~Gy}$.

W całej grupie 286 chorych po RT-ChT oceniono częstość całkowitych remisji (CR). Dokonano tego na podstawie badań tomografii komputerowej klatki piersiowej. Następnie w grupie chorych z CR, u których okres obserwacji po leczeniu wynosił przynajmniej 6 miesięcy, oceniono częstość i czas rozwoju zmian popromiennych w płucach, ze szczególnym uwzględnieniem rozwoju zwłóknienia płuc oraz towarzyszących im objawów klinicznych.

W ocenie zmian popromiennych w płucach, stwierdzanych $w$ radiologicznych badaniach obrazowych klatki 
piersiowej, stosowano klasyfikację proponowaną przez Fleischner Society [24], natomiast w ocenie stopnia nasilenia powikłań w płucach wykorzystano skalę toksyczności wg Common Terminology Criteria for Adverse Events (CTCAE) v.4 [25].

Przeprowadzono ocenę wpływu czynników klinicznych (wiek, płeć) i czynników związanych z leczeniem (sposób kojarzenia RT-ChT, czas rozpoczynania RT względem ChT oraz wartości dozymetryczne: maksymalnej dawki w płucach [MaxLD], średniej dawki w płucach [MLD] i V20, czyli objętości płuc, która otrzymała dawkę równą lub większą niż 20 Gy) na częstość rozwoju powikłań w płucach.

\section{Metody statystyczne}

W analizie statystycznej punktami końcowymi były: wystąpienie powikłań w płucach (u chorych z CR i przynajmniej 6-miesięcznym okresem obserwacji po leczeniu) oraz odsetki 3-letniego przeżycia bez objawów nowotworu (ocenione w całej grupie chorych).

W ocenie częstości wystąpienia powikłań w płucach w zależności od badanego czynnika stosowano test $\chi^{2}$, natomiast w przypadku porównywania średnich wartości badanych parametrów stosowano analizę wariancji ( $z$ użyciem testów: t-Student, Mann-Whitney - w zależności od liczebności porównywanych grup).

Dodatkowo, w całej grupie 286 chorych, oszacowano przeżycia bezobjawów nowotworu w zależności od tych czynników związanych z leczeniem, w przypadku których stwierdzono istotny wpływ na częstość rozwoju powikłań popromiennych w płucach. W tym celu stosowano metodę Kaplana-Meiera, a uzyskane wyniki porównano testem log-rank.

We wszystkich prowadzonych analizach statystycznych przyjęto poziom istotności $a=0,05$. Analizy wykonane zostały programem Statistica firmy StatSoft.

\section{Wyniki}

Spośród 286 chorych na DKRP OP u 187 chorych $(65,4 \%)$ po RT-ChT uzyskano CR. Okres obserwacji wynoszący przynajmniej 6 miesięcy dotyczył 152 chorych $(81,3 \%)$ z CR i ta grupa była przedmiotem dalszej analizy dotyczącej rozwoju powikłań w płucach.

W tabeli I przedstawiono charakterystykę kliniczną oraz dane dotyczące leczenia w podgrupie 152 chorych z CR i przynajmniej 6-miesięcznym okresem obserwacji po leczeniu.

Wiek chorych wahał się od 32 do 79 lat i wynosiłśrednio 59,5 roku (mediana: 58 lat). W tej grupie większość stanowili mężczyźni (89/152 - 58,6\%).

U 75 chorych (49,3\%) zastosowano równoczesną RT-ChT, a RT na obszar nowotworu w klatce piersiowej stosowana po 1-2 cyklu ChT przeprowadzona została u 68 chorych (44,7\%). Większość (123/152 chorych - 80,9\%) otrzymała dawkę równą lub większą od 54 Gy. Średnie wartości parametrów: MaxLD, MLD i V20 wynosiły odpowiednio: $57 \pm 4,9 \mathrm{~Gy}, 16,6 \pm 3,2$ Gy i $30,5 \pm 6,8 \%$.

W grupie 152 chorych z CR i przynajmniej 6-miesięcznym okresem obserwacji średni czas obserwacji wynosił 31,6 miesiąca (zakres: 6-135 miesięcy).

U 132 chorych (86,8\%) w badaniach obrazowych klatki piersiowej stwierdzono rozwój powikłań w płucach. Zmiany te wystąpiły średnio w czasie 3,6 miesiąca (zakres: 1-24 miesiące) po zakończeniu leczenia. Chorzy ci stanowili 70,6\% spośród 187 chorych z potwierdzoną CR i 46,2\% wszystkich 286 chorych na DKRP OP.

W tabeli II zestawiono częstość i stopień nasilenia powikłań w płucach oraz towarzyszące im objawy kliniczne.

U 91 spośród 132 chorych (68,9\%) w badaniach obrazowych średnio $\mathrm{w}$ czasie 7,4 miesiąca po zakończeniu leczenia stwierdzono zwłóknienie płuc. Chorzy ci stanowili $48,7 \%$ z CR i 31,8\% wszystkich DKRP OP. Innymi zmianami stwierdzanymi w badaniach obrazowych były zagęszczenia pęcherzykowo-zrębowe (74 chorych - 56,1\%) i pogrubienie rysunku zrębu ( 24 chorych - 18,2\%). Zmiany te u 54 chorych towarzyszyły zwłóknieniu (zagęszczenia pęcherzykowo-zrębowe u 44 chorych, a pogrubienie rysunku zrębu u 10) albo występowały samodzielnie (41 chorych).

U 96 chorych spośród 132 (72,7\%) zmianom popromiennym w płucach stwierdzonym w badaniach obrazowych towarzyszyły objawy kliniczne. Najczęstszymi z nich były duszność (67 chorych - 69,8\%) i kaszel (56 chorych $-58,3 \%)$.

Ocena stopnia nasilenia powikłań w płucach wg CTCAE wykazała, że u zdecydowanej większości chorych (95,6\%) zmiany te były słabo nasilone (G1).

Przeprowadzono ocenę wpływu czynników klinicznych i związanych z leczeniem na częstość rozwoju powikłań w płucach. Wyniki tych analiz zestawiono w tabelach III i IV.

Stwierdzono, że powikłania płucne istotnie częściej występowały u chorych, którzy otrzymali równoczesną RT-ChT (powikłania u 93,3\% w porównaniu z 80,5\% po sekwencyjnej RT-ChT), gdy RT stosowana była po 1-2 cyklu ChT (95,6\% vs 79,8\% w porównaniu z RT rozpoczynaną po 3. cyklu lub później) oraz gdy dawka całkowita wynosiła ponad $54 \mathrm{~Gy}$.

Ponadto wykazano, że w przypadku stosowania równoczesnej RT-ChT oraz RT rozpoczynanej po 1-2 cyklu ChT powikłania w płucach rozwijały się istotnie wcześniej. Średni czas rozwoju powikłań wynosił 2,9 mies. dla równoczesnej RT-ChT i 3 mies. dla RT po 1-2 cyklu ChT, w porównaniu z 4,2 mies. w przypadku sekwencyjnej RT-ChT i RT rozpoczynanej po 3 cyklu lub później.

Powikłania płucne częściej obserwowane były u kobiet (88,9\% vs 85,3\% u mężczyzn) oraz u młodszych chorych (średnia wieku wynosiła 59 lat w porównaniu z 62,7 u chorych, u których nie wystąpiły powikłania), jednak różnice te nie były statystycznie istotne. 
Tabela II. Powikłania płucne: zmiany stwierdzane w badaniach obrazowych klatki piersiowej oraz towarzyszące im objawy kliniczne

\begin{tabular}{lcc}
\hline Czynnik & Liczba chorych & $\%$ \\
\hline Zmiany radiologiczne & 132 & 86,8 \\
(klasyfikacja wg Fleischner Society): & & 68,9 \\
zwłóknienie płuc & 91 & 56,1 \\
zagęszczenia pęcherzykowo-zrębowe & 74 & 18,2 \\
pogrubienie rysunku zrębu & 24 & 61,9 \\
Wspótistniejące objawy kliniczne: & & 69,8 \\
duszność & 96 & 58,3 \\
kaszel & 67 & 14,6 \\
osłabienie & 56 & 3,1 \\
gorączka & 14 & 95,6 \\
Stopień nasilenia zwłóknienia płuc (wg skali CTCAE v. 4): & 3 & 4,4 \\
G1 & & \\
G2 & 87 & \\
\hline
\end{tabular}

Tabela III. Wyniki analizy oceny wpływu czynników klinicznych i terapeutycznych na rozwój powikłań płucnych

\begin{tabular}{|c|c|c|c|c|c|}
\hline \multirow[t]{3}{*}{ Czynniki } & \multicolumn{4}{|c|}{ Powikłania płucne } & \multirow[t]{3}{*}{$\mathrm{p}$} \\
\hline & \multicolumn{2}{|c|}{ Tak (132 chorych) } & \multicolumn{2}{|c|}{ Nie (20 chorych) } & \\
\hline & Liczba chorych & $\%$ & Liczba chorych & $\%$ & \\
\hline \multicolumn{6}{|l|}{ Płeć: } \\
\hline kobiety & 56 & 88,9 & 7 & 11,1 & 0,5267 \\
\hline mężczyźni & 76 & 85,3 & 13 & 14,7 & \\
\hline \multicolumn{6}{|l|}{ RT-ChT: } \\
\hline równoczesna & 70 & 93,3 & 5 & 6,7 & 0,0141 \\
\hline sekwencyjna & 62 & 80,5 & 15 & 19,5 & \\
\hline \multicolumn{6}{|c|}{ RT obszaru klatki piersiowej: } \\
\hline po 1-2 cyklu PE & 65 & 95,6 & 3 & 4,4 & 0,0025 \\
\hline po $\geq 3$ cyklu PE & 67 & 79,8 & 17 & 20,2 & \\
\hline \multicolumn{6}{|l|}{ Dawka całkowita (PTV): } \\
\hline$<50 \mathrm{~Gy}$ & 8 & 72,7 & 3 & 27,3 & \\
\hline$\geq 50 \mathrm{~Gy}-<54 \mathrm{~Gy}$ & 16 & 88,9 & 2 & 11,1 & \\
\hline$\geq 54 \mathrm{~Gy}-\leq 56 \mathrm{~Gy}$ & 101 & 91,0 & 10 & 9,0 & 0,0033 \\
\hline$>56 \mathrm{~Gy}$ & 7 & 58,3 & 5 & 41,7 & \\
\hline \multicolumn{6}{|l|}{ V20 (\%) } \\
\hline$\leq 30$ & 74 & 88,1 & 10 & 11,9 & \\
\hline $32-40$ & 47 & 85,5 & 8 & 14,5 & 0,8769 \\
\hline$>40$ & 11 & 84,6 & 2 & 15,4 & \\
\hline \multicolumn{6}{|l|}{ MLD (Gy) } \\
\hline $11-20$ & 117 & 84,8 & 19 & 15,2 & 0,3469 \\
\hline $21-30$ & 15 & 93,8 & 1 & 6,2 & \\
\hline \multicolumn{6}{|c|}{ Zmienne ciągłe - średnia \pm OS: } \\
\hline wiek & \multicolumn{2}{|c|}{$59,0 \pm 8,9$} & & 0,0535 \\
\hline dawka całkowita (PTV) & \multicolumn{2}{|c|}{$56,4 \pm 3,7$} & \multicolumn{2}{|c|}{$53,8 \pm 5,2$} & 0,2474 \\
\hline MaxLD & \multicolumn{2}{|c|}{$57,1 \pm 4,8$} & \multicolumn{2}{|c|}{$58,6 \pm 5,7$} & 0,0890 \\
\hline MLD & \multicolumn{2}{|c|}{$16,6 \pm 3,2$} & \multicolumn{2}{|c|}{$16,4 \pm 3,2$} & 0,8041 \\
\hline V20 & \multicolumn{2}{|c|}{$30,5 \pm 6,9$} & \multicolumn{2}{|c|}{$30,9 \pm 6,7$} & 0,7109 \\
\hline
\end{tabular}

RT-ChT — radiochemioterapia, RT — radioterapia obszaru klatki piersiowej, PTV (planning target volume) — planowana objętość w radioterapii, V20 — objętość płuc (poza PTV), która otrzymała dawkę równą lub większą niż 20 Gy, MLD (mean lung dose) — średnia dawka, jaką otrzymały płuca (poza PTV), MaxLD (maximal lung dose) - maksymalna dawka w płucach, OS — odchylenie standardowe

Nie wykazano istotnego wpływu na rozwój powikłań w płucach parametrów dozymetrycznych: MaxLD, MLD, V20. Znaczenie tych czynników wykazane zostało po uwzględnieniu sposobu kojarzenia RT-ChT i czasu rozpoczynania RT.
Stwierdzono istotne różnice w średniej wartości MLD w zależności od sposobu kojarzenia RT-ChT (17,1 Gy vs 16,2 Gy odpowiednio dla: równoczesnej i sekwencyjnej RT-ChT $p=0,0471$ ), natomiast w przypadku czasu rozpoczynania RT takie różnice dotyczyły MaxLD iV20. Odpowiednio 
Tabela IV. Porównanie wartości parametrów dozymetrycznych i czasu rozwoju powikłań płucnych w zależności od sposobu przeprowadzania RT-ChT i rozpoczynania RT względem chemioterapii

\begin{tabular}{lcccccc}
\hline Parametry (średnie wartości) & \multicolumn{3}{c}{ Schemat RT-ChT } & \multicolumn{3}{c}{ RT obszaru kl. piersiowej } \\
\cline { 2 - 7 } & Równoczesna & Sekwencyjna & $\mathbf{p}$ & Po 1-2 cyklu PE & Po $\geq 3$ cyklu PE & p \\
\hline MaxLD (Gy) & 57,7 & 56,4 & 0,1309 & 57,5 & 56,5 & 0,0317 \\
MLD (Gy) & 17,7 & 16,2 & 0,0471 & 17,0 & 16,3 & 0,3759 \\
V20 (\%) & 31,7 & 30,2 & 0,7172 & 31,4 & 30,5 & 0,0260 \\
Czas rozwoju powikłań w płucach (miesiące) & 2,9 & 4,2 & 0,0325 & 3,0 & 4,2 & 0,0486 \\
\hline
\end{tabular}

MaxLD (maximal lung dose) —maksymalna dawka w płucach

MLD (mean lung dose) — średnia dawka, jaką otrzymały płuca (poza PTV)

V20 - objętość płuc (poza PTV), która otrzymała dawkę równą lub większą niż 20 Gy

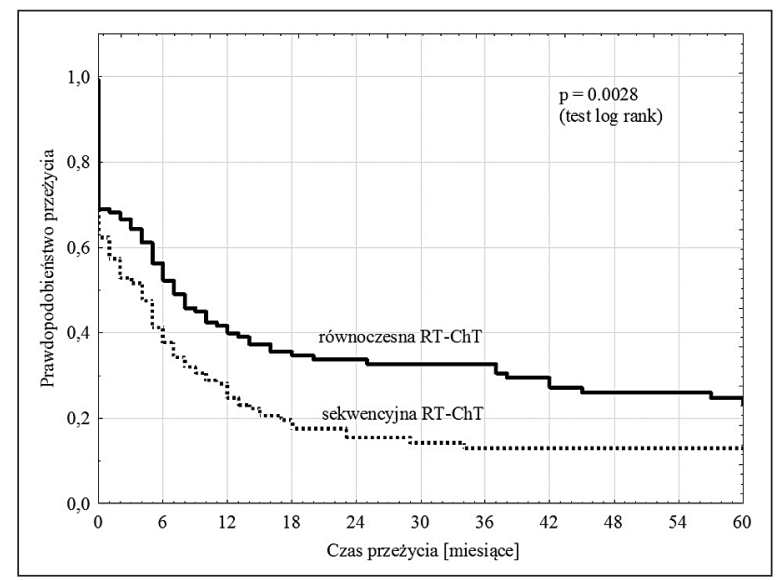

Rycina 1. Krzywe przeżycia bez objawów nowotworu w zależności od sposobu stosowania radiochemioterapii (RT-ChT) w grupie 286 chorych na DKRP OP, leczonych w latach 2000-2010

dla RT po 1-2 cyklu ChT i RT po 3 cyklu lub później wartości MaxLD wynosiły 57,5 Gy i 56,5 Gy (p=0,0317), a V20: 31,4\% i $30,5 \%(p=0,0260)$.

Ponieważ sposób kojarzenia RT-ChT oraz czas rozpoczynania RT okazały się istotnymi czynnikami dla rozwoju powikłań w płucach, dodatkowo, w całej grupie 286 chorych, oceniono wpływ tych czynników na odsetki przeżycia bez objawów nowotworu.

Na rycinach 1 i 2 przedstawiono krzywe przeżycia bez objawów nowotworu w zależności od sposobu kojarzenia RT-ChT (ryc. 1) i czasu rozpoczynania RT na obszar nowotworu w klatce piersiowej (ryc. 2).

Oszacowane 3-letnie odsetki przeżyć bez objawów nowotworu w zależności od sposobu kojarzenia RT-ChT wynosiły $32,7 \%$ vs $12,9 \%$ odpowiednio dla równoczesnej vs sekwencyjnej RT-ChT ( $p=0,0028)$. Odsetki te w zależności od czasu rozpoczynania RT względem ChT wynosiły: 36,8\% vs 14,8\% odpowiednio dla RT rozpoczynanej po 1-2 cyklu ChT vs po 3 cyklu lub później $(p=0,0001)$.

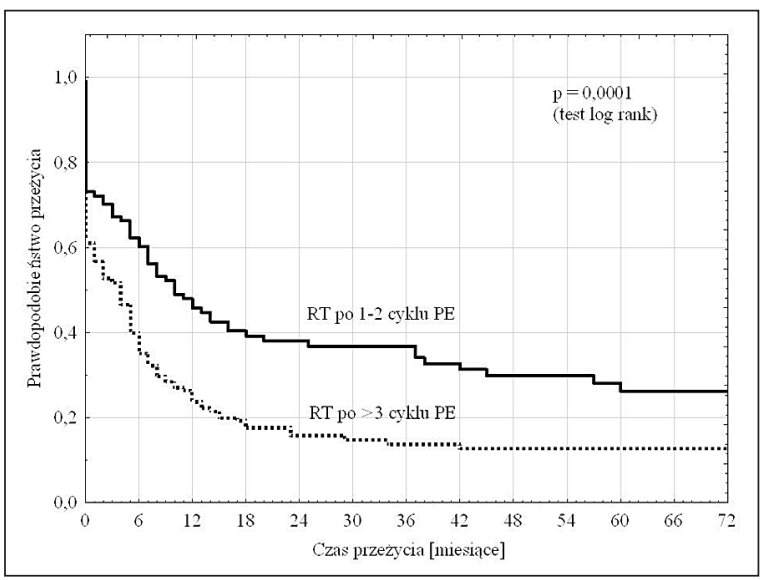

Rycina 2. Krzywe przeżycia bez objawów nowotworu w zależności od rozpoczynania radioterapii (RT) na obszar klatki piersiowej względem chemioterapii (po 1-2 cyklu PE vs po $\geq 3$ cyklu PE) w grupie 286 chorych na DKRP OP, leczonych w latach 2000-2010

\section{Omówienie}

W radioterapii stosowanej u chorych na raka płuca mamy do czynienia ze szczególną sytuacją: objętość wymagająca leczenia (co związane jest z koniecznością podania dawki terapeutycznej) znajduje się w obrębie narządu wrażliwego na uszkodzenia popromienne. Do najważniejszych czynników związanych z RT, których wartość koreluje z ryzykiem rozwoju powikłań popromiennych w płucach, należą: objętość płuc otrzymująca dawkę powyżej 20 Gy (V20) oraz średnia dawka, jaką otrzymują płuca (MLD) [26-28].

Innymi czynnikami wpływającymi na zwiększenie ryzyka rozwoju powikłań jest stosowanie równoczesnej RT-ChT oraz stosowanie schematów przyspieszonej frakcjonacji dawki w RT [21, 29-32].

Po radykalnej RT stosowanej na obszar klatki piersiowej istnieje ryzyko związane z rozwojem objawów popromiennego zapalenia płuc (radiation pneumonitis). Powikłanie to zazwyczaj rozwija się w okresie od 4 tyg. do 6 mies. po zakończeniu RT $[33,34]$. Objawy kliniczne objawiają się kaszlem, gorączką 
i dusznością. Objawom tym towarzyszą zmiany w badaniach obrazowych klatki piersiowej (zacienienia i plamiste nacieki), które zazwyczaj są obecne na większym obszarze płuc niż napromieniana objętość [30, 31, 35]. W dalszym przebiegu klinicznym zmiany te mogą ulec regresji, utrzymywać się lub - w ciągu miesięcy lub lat — przejść w fazę przewlekłą, którą jest zwłóknienie płuc [26, 36]. Zaznaczyć należy, że popromienne zwłóknienie płuc może rozwinąć się bez poprzedzającego go popromiennego zapalenia płuc. Objętość płuc, w której rozwija się zwłóknienie, koreluje z napromienianą objętością.

Zwłóknienie płuc jest procesem nieodwracalnym, mogącym przebiegać bezobjawowo albo będącym czynnikiem odpowiedzialnym za rozwój niewydolności oddechowej oraz nadciśnienia płucnego. Szczególnie dotyczy to chorych, u których napromieniano dużą objętość płuc [37-39].

W przedstawionej grupie 152 chorych na DKRP OP z CR po RT-ChT u 132 chorych (86,8\%) w badaniach obrazowych klatki piersiowej stwierdzono: zwłóknienie płuc, zagęszczenia pęcherzykowo-zrębowe oraz pogrubienie rysunku zrębu. Wśród wymienionych zmian dominowało zwłóknienie płuc, które stwierdzono u 91 chorych (68,9\%). Chorzy ci stanowili $58,7 \%$ wszystkich chorych z CR i 31,8\% wszystkich chorych leczonych z powodu DKRP OP. U 96 spośród 132 chorych $(72,7 \%)$ zmianom stwierdzanym w badaniach radiologicznych towarzyszyły objawy kliniczne. Najczęstszymi objawami były duszność (69,8\%) i kaszel (58,3\%). Jednak ocena nasilenia zmian według skali CTCAE wykazała, że u 95,6\% chorych powikłania były w stopniu G1. Oznacza to, że zmiany widoczne w badaniach obrazowych były o niewielkim nasileniu i obecne były w stosunkowo małej objętości płuc. Ponadto z puntu widzenia klinicznego chorzy ci nie wymagali stosowania farmakoterapii.

Według piśmiennictwa powikłania płucne rozwijają się u 5-20\% chorych, u których napromieniany jest obszar klatki piersiowej [30]. Doniesienia dotyczące rozwoju popromiennego zwłóknienia płuc przede wszystkim dotyczą chorych na niedrobnokomórkowego raka płuca i autorzy wskazują na kluczowe znaczenie w jego rozwoju, wielkości podanej dawki i innych parametrów dozymetrycznych (V20, MLD). Istotną rolę w rozwoju powikłań w płucach odgrywają również: stosowanie leczenia skojarzonego, niekonwencjonalne schematy frakcjonowania dawki oraz parametry związane z chorym (wiek, płeć, palenie papierosów, stopień wydolności układu oddechowego) [27, 28, 30-32, 40].

W przypadku RT u chorych na DKRP zazwyczaj stosowana jest mniejsza dawka, a doniesienia w piśmiennictwie najczęściej dotyczą rozwoju radiation pneumonitis [21]. Należy zwrócić uwagę, że u chorych na DKRP OP zalecane jest stosowanie leczenia skojarzonego według schematów równoczesnej RT-ChT, z wczesnym rozpoczynaniem RT na obszar nowotworu w klatce piersiowej [2-10]. Wszystkie te czynniki wpływają na nasilenie toksyczności leczenia.

Obserwacje własne wykazały istotne znaczenie sposobu kojarzenia RT-ChT, czasu rozpoczynania RT oraz wielkości podanej dawki dla częstości rozwoju późnych powikłań w płucach. Stosowanie równoczesnej, w porównaniu z sekwencyjną, RT-ChT i RT rozpoczynaną po 1-2 cyklu ChT w porównaniu z RT prowadzoną po 3 cyklu lub później związane było ze zwiększeniem częstości powikłań w płucach odpowiednio o $14,2 \%$ i 7,8\%. Wykazano również, że te dwa parametry istotnie wpływały na wcześniejszy rozwój powikłań w płucach o ok. 1,3 mies.

Wartości parametrów związanych z radioterapią, do których należą MLD i V20, są znanymi czynnikami ryzyka rozwoju powikłań w płucach [27, 28, 30, 35], jednak, prezentowane wyniki nie potwierdziły wpływu wartości MaxLD, V20 i MLD na częstość ich rozwoju. Dopiero dalsza analiza oceny wpływu tych parametrów, przeprowadzona po uwzględnieniu sposobu kojarzenia RT-ChT i czasu rozpoczynania RT, wykazała ich istotne znaczenie. Stwierdzono, że wartość MLD była istotnie wyższa w przypadku równoczesnej, w porównaniu z sekwencyjną, RT-ChT (17,1 Gy vs 16,2 Gy). Natomiast w przypadku RT po 1-2 cyklu ChT wartości MaxLD i V20 były istotnie wyższe (57,5 Gy i 31,4\%) w porównaniu z RT stosowaną później (56,5\% i 30,5\%). Różnice te mogły wynikać z różnej wielkości objętości napromienianej w zależności od sposobu kojarzenia RT-ChT.

Przedstawione dane wskazują na istotne znaczenie sposobu kojarzenia RT-ChT i wpływu czasu rozpoczęcia RT na rozwój powikłań w płucach u chorych na DKRP OP. Należy zwrócić uwagę, że zarówno obserwacje własne (aktualnie prezentowane i wcześniejsze), jak i dane z piśmiennictwa wskazują, że te dwa parametry istotnie wpływają na wyniki leczenia u chorych na DKRP OP $[41,42,43]$.

\section{Wnioski}

Sposób kojarzenia RT-ChT oraz czas rozpoczynania RT są czynnikami, które u chorych na DKRP OP istotnie wpływają nie tylko na wyniki leczenia (przeżycia bez objawów nowotworu), ale również na częstość rozwoju powikłań w płucach.

Powikłania w płucach stwierdzone w badaniach obrazowych dotyczyły $85,2 \%$ chorych z CR po RT-ChT. Chorzy ci stanowili $46,2 \%$ wszystkich chorych leczonych z powodu DKRP OP.

Najczęstszym powikłaniem było zwłóknienie płuc, które stwierdzono u 68,9\% chorych z CR, co stanowiło 31,8\% wszystkich chorych leczonych powodu DKRP OP.

Stopień nasilenia powikłań w płucach u 95,6\% był w skali G1, a u pozostałych w skali G2, co wskazuje na niewielki wpływ na jakość życia u chorych z CR po RT-ChT z powodu DKRP OP. 


\section{Konflikt interesu: nie zgłoszono}

\section{Prof. nadzw. dr hab. n. med. Beata Sas-Korczyńska}

Klinika Onkologii, Oddział Nowotworów Piersi

i Klatki Piersiowe

Centrum Onkologii — Instytut im. Marii Skłodowskiej-Curie

Oddział w Krakowie

ul. Garncarska 11, 31-115 Kraków

e-mail:z5korczy@cyf-kr.edu.pl

Otrzymano: 3 lipca 2014 r.

Przyjęto do druku: 14 sierpnia $2014 \mathrm{r}$.

\section{Piśmiennictwo}

1. Siegel R, Naishadham D, Jemal A. Cancer statistics, 2013. CA Cancer J Clin 2013; 63: 11-30.

2. Jett JR, Schild SE, Kesler KA, Kalemkerian GP. Treatment of small cell lung cancer" Diagnosis and management of lung cancer, $3^{\text {rd }}$ ed: American College of Chest Physicians evidence-based clinical practice guidelines. Chest 2013; 143 (5 Suppl.): e400S-419S.

3. Cuffe $S$, Moua T, Summerfield R i wsp. Characteristics and outcomes of small cell lung cancer patients diagnosed during two lung cancer computed tomographic screening programs in heavy smokers. J Thorac Oncol 2011; 6: 818-822.

4. Sorensen M, Pijls-Johannasma M, Felip E. Small-cell lung cancer: ESMO Clinical Practice Guidelines for diagnosis, treatment and follow up. Ann Oncol 2010; 21 (Suppl 5): 120-125.

5. Paumier A, Le Pechoux C. Radiotherapy in small-cell lung cancer: where should it go? Lung Cancer 2010; 69: 133-140.

6. Videtic GM. The role of radiation therapy in small cell lung cancer. Curr Oncol Rep 2013; 15: 405-410.

7. Planchard D, Le Pechoux C. Small cell lung cancer: new recommendations and current status of biomarker assessment. Eur J Cancer 2011; 47 (Suppl 3): S272-283.

8. Fruh M, De Ruysscher D, Popat S i wsp. Small-cell lung cancer (SCLC): ESMO Clinical Practice Guidelines for diagnosis, treatment and follow-up. Ann Oncol 2013; 24 (Suppl. 6): 99-105.

9. Goldberg SB, Willers $\mathrm{H}$, Heist RS. Multidisciplinary management of small cell lung cancer. Surg Oncol Clin N Am 2013; 22: 329-343.

10. Van Meerbeeck JP, Fennel DA, De Ruysscher DK. Small-cell lung cancer. Lancet 2011; 378: 1741-1755.

11. Perry MC. Thoracic radiation therapy in limited stage small-cell lung cancer: timing is everything ... isn't it? J Clin Oncol 2006; 24: 3815-3816.

12. Slotman BJ, Senan S. Radiotherapy in small-cell lung cancer: lessons learned and future directions. Int J Radiat Oncol Biol Phys 2011; 79: 998-1003.

13. Erridge SC, Murray N. Thoracic radiotherapy for limited-stage small cell lung cancer: issues of timing, volumes, dose, and fractionation. Semin Oncol 2003; 30: 26-37.

14. Fried DB, Morris DE, Poole C i wsp. Systematic review evaluating the timing of thoracic radiation therapy in combined modality therapy for limited-stage small-cell lung cancer. J Clin Oncol 2004; 22: 4837-4845.

15. De Ruysscher D, Pijls-Johannesma M, Vansteenkiste J i wsp. Systematic review and meta-analysis of randomised, controlled trials of the timing of chest radiotherapy in patients with limited-stage, small-cell lung cancer. Ann Oncol 2006; 17: 543-552.

16. Spiro SG, James LE, Rudd RM i wsp. Early compared with late radiotherapy in combined modality treatment for limited disease small-cell lung cancer: a London Lung Cancer Group multicenter randomized clinical trial and meta-analysis. J Clin Oncol 2006; 24: 3823-3830.

17. Manapov F, Klocking S, Niyazi M i wsp. Chemoradiotehrapy duration correlates with overall survival in limited disease SCLC patients with poor initial performance status who successfully completed multimodality treatment. Strahlenther Onkol 2012; 188: 29-34.

18. Schild SE, Bonner JA, Hillman S i wsp. Results of a phase II study of high-dose thoracic radiation therapy with concurrent cisplatin and etoposide in limited-stage small-cell lung cancer (NCCTG 95-20-53). J Clin Oncol 2007; 25: 3124-3129.

19. Geara FB, Komaki R, Tucker SL i wsp. Factors influencing the development of lung fibrosis after chemoradiation for small cell carcinoma of the lung: evidence for inherent interindividual variation. Int J Radiat Oncol Biol Phys 1998; 41: 279-286.
20. De Ruysscher D, Van Meerbeek J, Vandecasteele K i wsp. Radiation-induced oesophagitis in lung cancer patients. Is susceptibility for neutropenia a risk factor? Strahlenther Onkol 2012; 188: 564-567.

21. Tsujino K, Hirota S, Kotani Y i wsp. Radiation pneumonitis following concurrent accelerated hyperfractionated radiotherapy and chemotherapy for limited-stage small-cell lung cancer: dose-volume histogram analysis and comparison with conventional chemoradiation. Int J Radiat Oncol Biol Phys 2006; 64: 1100-1105.

22. Myers JN, O'Neil KM, Walsh TE i wsp. The pulmonary status of patients with limited-stage small cell lung cancer 15 years after treatment with chemotherapy and chest irradiation. Chest 2005; 128: 3261-3268.

23. Sloan JA, Bonner JA, Hillman SL i wsp. A quality-adjusted reanalysis of a phase III trial comparing once-daily thoracic radiation vs. twice-daily thoracic radiation in patients with limited-stage small-cell lung cancer. Int J Radiat Oncol Biol Phys 2002; 52: 371-381.

24. Hansell DM, Bankier AA, MacMahon H i wsp. Fleischner Society: Glossary of terms for thoracic imaging. Radiology 2008; 246: 697-722.

25. http://evs.nci.nih.gov/ftp1/CTCAE/CTCAE4.03 2010-06-14QuickReference5x7.pdf.

26. Kong FM, Hayman JA, Griffith KA i wsp. Final toxicity of a radiation-dose escalation study in patients with non-small-cell lung cancer (NSCLC): predictors for radiation pneumonitis and fibrosis. Int J Radiat Oncol Biol Phys 2006; 65: 1075-1086.

27. Graham MV, Purdy JA, Emami B i wsp. Clinical dose-volume histogram analysis for pneumonitis after 3D treatment for non-small cell lung cancer (NSCLC). Int J Radiat Oncol Biol Phys 1999; 45: 323-329.

28. Hernando ML, Marks LB, Bentel GC i wsp. Radiation-induced pulmonary toxicity: a dose-volume histogram analysis in 201 patients with lung cancer. Int J Radiat Oncol Biol Phys 2001; 51: 650-659.

29. Bradley JD, Hope A, El Naqa I i wsp. A normogram to predict radiation pneumonitis, derived from a combined analysis of RTOG 9311 and institutional data. Int J Radiat Oncol Biol Phys 2007; 69: 985-992.

30. Mehta V. Radiation pneumonitis and pulmonary fibrosis in non-small-cell lung cancer: Pulmonary function, prediction, and prevention. Int J Radiat Oncol Biol Phys 2005; 63: 5-24.

31. Rodrigues G, Lock M, D'Souza Di wsp. Prediction of radiation pneumonitis by dose-volume histogram parameters in lung cancer - a systematic review. Radiother Oncol 2004; 71: 127-138.

32. Roeder F, Friedrich J,Timke C i wsp. Correlation of patient-related factors and dose-volume histogram parameters with the onset of radiation pneumonitis in patients with small cell lung cancer. Strahlenther Onkol 2010; 186: 149-156.

33. Hope AJ, Lindsay PE, El Naqa I i wsp. Modeling radiation pneumonitis risk with clinical, dosimetric, and spatial parameters. Int J Radiat Oncol Biol Phys 2006; 65: 112-124.

34. Schneider RA, Schultze J, Jensen JM i wsp. 20 years of experience in static intensity-modulated total body irradiation and lung toxicity. Strahlenther Onkol 2007; 183: 545-551.

35. Skinner R, Kaplan R, Nathan P. Renal and pulmonary late effects of cancer therapy. Sem Oncol 2013; 40: 757-773.

36. Morgan GW, Breit SN. Radiation and the lung: A reevaluation of the mechanisms mediating pulmonary injury. Int J Radiat Oncol Biol Phys 1995; 31: 361-369.

37. Graves PR, Siddiqui F, Anscher MS i wsp. Radiation pulmonary toxicity: from mechanisms to management. Semin Radiat Onco/2010;20:201-207.

38. Medhora M, Gao F, Jacobs ER, Moulder JE. Radiation damage to the lung: mitigation by angiotensin-converting enzyme (ACE) inhibitors. Respirology 2012; 17: 66-71.

39. Evans ES, Hahn CA, Kocak Z i wsp. The role of functional imaging in the diagnosis and management of late normal tissue injury. Semin Radiat Oncol 2007; 17: 72-80.

40. Willner J, Baier K, Caragiani E i wsp. Dose, volume, and tumor contro prediction in primary radiotherapy of non-small-cell lung cancer. Int $J$ Radiat Oncol Biol Phys 2002; 52: 382-389.

41. Tsukada H, Yokoyama A, Goto K, Takada M, Saijo N, and the Japan Clinical Oncology Lung Cancer Study Group. Concurrent versus sequential radiotherapy for small cell lung cancer. Semin Oncol 2001; 28 (2 Suppl. 4): 23-26.

42. De Ruysscher D, Belderbos J, Reymen B i wsp. State of the art radiation therapy for lung cancer 2012: a glimpse of the future. Clin Lung Cancer 2013; 14: 89-95.

43. Rossi A, Martelli O, Di Maio M. Treatment of patients with small-cell lung cancer: from meta-analyses to clinical practice. Cancer Treat Rev 2013; 39: 498-506. 